\title{
CORPORATE CRIMINAL LIABILITY REGARDING IUU FISHING FOLLOWING THE JOB CREATION LAW ENACTMENT
}

\author{
Ayu Izza Elvany \\ Faculty Of Law Universitas Islam Indonesia
}

\begin{abstract}
This research analyses how is corporate criminal liability regulation in Indonesia regarding IUU Fishing following the enactment of the Job Creation Law. This research uses both statute approach and conceptual approach as the legal research methods to analyse the issued legal problem. Following the enactment of the Job Creation Law on $5^{\text {th }}$ October 2020, some articles of Law No. 45 of 2009 amending law no. 31 of 2004 concerning Fishery are amended, including the corporate criminal liability regulation. This research's analyses shows that in order to improve the effectiveness of IUU Fishing law enforcement, specifically the ones being committed by a corporation, the Job Creation Law needs to be amended, specifically its article concerning corporate criminal liability, by changing the used conjunction to 'and/or, as regulated in the draft of Fishery Law as well. Furthermore, as the term of 'person in charge' is more appropriate, in case of corporate criminal liability system, than the one used in the Job Creation Law, which is 'employee', the Job Creation Law shall be revised by opting the former term into it.
\end{abstract}

Keywords:

Corporate Criminal Liability, IUU Fishing, Job Creation Law

\begin{abstract}
Abstrak
Penelitian ini menganalisis bagaimana pengaturan pertanggung jawaban pidana korporasi di Indonesia terkait IUU Fishing pasca berlakunya UU Cipta Kerja. Penelitian ini menggunakan pendekatan undang-undang dan pendekatan konseptual sebagai metode penelitian hukum untuk menganalisis masalah hukum yang dikeluarkan. Menyusul berlakunya UU Cipta Kerja pada 5 Oktober 2020, beberapa pasal UU No. 45 Tahun 2009 mengubah UU No. 31 Tahun 2004 tentang Perikanan diubah, termasuk peraturan pertanggungjawaban pidana korporasi. Analisis penelitian ini menunjukkan bahwa untuk meningkatkan efektivitas penegakan hukum IUU Fishing khususnya yang dilakukan oleh korporasi, maka UU Cipta Kerja perlu diubah, khususnya pasalnya tentang pertanggungjawaban pidana korporasi, dengan mengubah konjungsi yang digunakan menjadi ' dan/atau sebagaimana diatur dalam RUU Perikanan. Selanjutnya, karena istilah 'penanggung jawab' lebih tepat, dalam hal sistem pertanggungjawaban
\end{abstract}


pidana korporasi, daripada yang digunakan dalam UU Cipta Kerja yaitu 'pegawai', maka UU Cipta Kerja harus direvisi dengan memilih yang pertama. istilah ke dalamnya.

Kata Kunci:

Tanggung Jawab Pidana Perusahaan, IUU Fishing, UU Penciptaan Lapangan Kerja

\section{A. INTRODUCTION}

7 he enactment of Law No. 11 of 2020 on Job Creation, which occurred amid the still-covid19 outbreak, becomes one of the controversial topics nowadays. Based on its considerations, the purpose of the Job Creation Law is to ensure the acceleration of job creation in the midst of increasing competition and economic globalization's demands by amending several sectoral laws, including Law No. 45 of 2009 amending law no. 31 of 2004 concerning Fishery. As one of the sectoral law that is revised by the Job Creation Law, many fishery-concerned-organizations have stated their rejections since its substance less prioritize the sustainability of fisheries resources and its ecosystem hence it might hinder the sustainable development goals achievement.

The Fishery Law as a penal policy of Illegal, Unreported and Unregulated (IUU) Fishing eradication regulates criminal law as one of its enforcement instrument. However, the Job Creation Law amended several articles of the Fishery Law, including corporate criminal liability provision. Since IUU Fishing is mostly committed in order to gain financial benefit, the Fishery Law not only recognized natural person as a legal person but also corporations. In fact, there are cases of IUU Fishing that were conducted by corporations such as MV Hai Fa case and the case of KM Sino 35.

Regarding MV Hai Fa case, based on the Ambon District Court Decision No. No. 01/Pid.Sus/PRK/2015/PN Amb, which strengthens by the Maluku High Court, the defendant is Zhu Nian Le, the captain of the MV Hai Fa. He was proven guilty of illegal fishing by violating Article 100 jo Article 7 (2) paragraph m of the Fishery Law therefore he was sentenced to a fine of $\mathrm{Rp} 200$ million. Furthermore, the owner of both $800.658 \mathrm{~kg}$ of fish and $100.044 \mathrm{~kg}$ of shrimps, as stated in the court decision, which carried by the vessel was Avona Mina Lestari Ltd. Nevertheless, there were no criminal charges against the corporation despite the mentioned fact.

As for KM Sino 35 case, Supreme Court Decision No. 2485 K/PID.SUS/2015 stated that the defendants were Gou Xianging as Fishing Master of the ship and Juli Prasetya the captain of the ship. Both of them were the employees of Sino Shunlinda Fishing Ltd which was the owner of the ship. The defendants were proven guilty by perpetrating illegal fishing of Article 85 jo Article 9 of the Fishery Law hence they were sentenced to 1 year and 6 months of prison and a fine of $\mathrm{Rp} 1$ billion with a substitute of 6 months of jail. In this case, it was revealed that the corporation was not charged criminally despite being the owner of the ship and might be the recipient of illicit profit gained by the defendants. 
The cases mentioned above indicated that there were no criminal charges against any of them albeit their involvement. For that reason, the question is whether the Fishery Law regulates corporate criminal liability or the corporations are merely avowed as legal entity hence can not be held criminally liable. Moreover, the Job Creation Law has amended several articles of the Fishery Law including the article concerning corporate criminal liability. Thus this research will analyses further how is corporate criminal liability regulation in Indonesia regarding IUU Fishing following the enactment of the Job Creation Law. Even though there are already many kinds of research about corporate criminal liability of IUU Fishing, this research will specifically, as stated above, analyses it based on the recent Fishery Law which is revised by the Job Creation Law since its enactment on $5^{\text {th }}$ October 2020. Consequently, the result of this research's analysis can contribute to improving the existing Fishery Law, particularly corporate criminal liability regulations, to optimize the effectiveness of IUU Fishing enforcement in this globalization era.

\section{B. RESEARCH METHOD}

This research uses both statute approach and conceptual approach as the legal research methods to analyse the issued legal problem. The statute approach is a process of elaborating on the provisions and regulations concerning the said legal issue. Regarding the conceptual approach, this research will refers to the statutes and several doctrines relating the concerned problem. Both approaches are used not only to analyse the issued legal problem but also to present the solution of it.

\section{CORPORATE CRIMINAL LIABILITY REGARDING IUU FISHING FOLLOWING THE JOB CREATION LAW ENACTMENT}

In the criminal law point of view, as stated by Sjahdeini, a corporation can be defined as both legal entities, such as limited company and foundation, and non-legal entity, such as maatschap and firms. ${ }^{1}$ Furthermore, black's law dictionary defined a corporation as an entity having authority under law to act as a single person distinct from the shareholders who own it and having rights to issue stock and exist indefinitely, a group or succession of persons established in accordance with legal rules into a legal or jurist person that has a legal personality distinct from the natural persons who make it up, exist indefinitely apart from them, and has the legal powers that constitution gives it. ${ }^{2}$

Corporate criminal liability is regulated in law is a consequence of the recognition of corporate as a legal person in it. ${ }^{3}$ Additionally, Mardjono Reksodiputro

\footnotetext{
${ }^{1}$ Sjahdeini, S.R.. (2006). Pertanggungjawaban pidana korporasi. Jakarta: Grafiti Pers retrieved from Oksimana Darmawan, Pertanggungjawaban Pidana Korporasi Dalam Illegal Fishing Di Indonesia, Jurnal Yudisial Vol. 11 No. 2 Agustus 2018: 171 - 192

${ }^{2}$ Garner, Bryan A (editor in chief), black's law dictionary, seventh edition, paul, minim, west publishing Co, 1999), pg. 341 retrieved from Yudi Krismen, Pertanggungjawaban Pidana Korporasi Dalam Kejahatan Ekonomi, Jurnal Ilmu Hukum Volume 4 No. 1 (2014)

${ }^{3}$ Muladi dan Dwidja Priyatno, Pertanggungjawaban Korporasi, Jakarta: Kencana Prenada Media Group, (2012), pg. 129
} 
argued that there are three categories of corporate criminal liability in Indonesia which are firstly, the laws that do not recognize corporations as a law subject, therefore, corporations cannot be held criminally liable and become the subject of punishment, secondly, the Laws which recognize criminal acts by corporations, but it is only the natural person within the corporation who can be held criminal liable on behalf of the corporation, and the last one, the Laws which recognize that a corporation is criminally liable and the subject of criminal punishment. ${ }^{4}$

Corporate liability is one of the main issues that raise the pros and cons in some circles, especially regarding the consequences of violating the law in the agency relationship in which inherent legal rights and obligations between the principal and agent. ${ }^{5}$ In criminal law, in cases where the law requires a guilty mind of directors or the managers will render the company themselves guilty. ${ }^{6}$ Corporate crime represents a greater disadvantage if compared to individual crime or commonly referred to as conventional/traditional crime. This is caused by the characteristics of the corporate crime itself, among others: First, the crime is difficult to be seen (low visibility), because it is usually covered by normal and routine work activities, involving professional skills and complex organizational systems. ${ }^{7}$

Secondly, the crime is complex (it always relates to lies, deception and theft and is often related to a scientific, technological, financial, legal, organized, and involving many people and runs for years. Third, the occurrence of spreading responsibility (diffusion of responsibility), which is increasingly widespread due to organizational complexity. Fourthly, diffusion of victims, such as pollution and fraud. Fifth, detection and prosecution barriers, as a result of unbalanced professionalism between the law enforcement apparatus and the perpetrators of the crime, and lastly, the ambiguous law that often causing the losses in enforcing the law, and the seventh, the dual attitude of the offender's status. ${ }^{8}$

Moreover, Vijay Veer Singh argued that to impose corporate criminal liability, there are two elements that must be present which are, first, the intended act must be within the scope of employment meaning that the employee shall be performing activities authorized by the company, second, the act must be benefiting the corporation meaning that it is inconsequential that the employee conducts an act

\footnotetext{
${ }^{4}$ Mardjono Reksodiputro, Pertanggungjawaban Pidana Korporasi dalam Tindak Pidana Korporasi (the Criminal Liability of Corporations in Corporate Crime), Presentation Paper in National Seminar on Corporate Crime, FH UNDIP, Semarang 23-24 November 1989, p. 9, retrieved from Maradona, Corporate Criminal Liability in Indonesia: Regulation, Implementation and Comparison with The Netherlands, Thesis, Erasmus school of law, 2018, pg. 96

${ }^{5}$ V. L. Hamilton, Who is Responsible? Toward a Social Psychology of Responsibility, Social Psychology, Vol 41, No. 4, (1978), pp. 316-328 retrieved from Henry Dianto Pardamean Sinaga, et. al.,, Reconstruction of Corporate Criminal Liability in Indonesia, International Journal of Advanced Science and Technology Vol. 29, No. 08, (2020), pp. 1231-1240

${ }^{6}$ Vikrant Sopan Yadav, Corporate Criminal Liability: A Comparative Analysis of Judicial Trend, International Journal of Applied Research 2015; 1(10): 756-760

${ }^{7}$ Setiyono. (Averros Press, Malang, 2002) retrieved from Rahadi Wasi Bintoro et. al., Corporate Criminal Liability towards The Doer of Illegal, Unregulated and Unreported Fishing in Indonesia, E3S Web of Conferences 47, 06003 (2018)

${ }^{8}$ Ibid

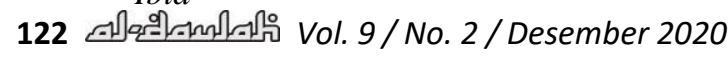


selflessly with no purpose making any personal gain or benefit. ${ }^{9}$ In addition, Catherine Elliott and Frances Quinn had already proposed several reasons for imposing corporate criminal liability, which were (1) without it, companies might escape regulation by the criminal law, and individuals could be prosecuted for offences which were really the fault of company practices, (2) In some cases, it is more convenient for procedural purposes to prosecute a company rather than its employee(s), (3) where an offence is serious, a company may be more likely to be able to pay the required level of excellent than an individual employee would be, (4) The threat of criminal prosecution may encourage shareholders to exercise control over the activities of companies in which they invest, (5) If a company has made a profit through an illegal practice, it should be the one to pay the price, not an employee, (6) Corporate liability can discourage companies from putting pressure on employees, directly or indirectly, to raise profits by acting illegally - for example, if a haulage firm sets its drivers targets for delivery times that those drivers could not meet without speeding, imposing corporate or vicarious liability would be a way of ensuring that the company does not get off scot-free if the driver is charged with speeding, (7) Adverse publicity and fines may act as a deterrent against acting illegally- this might not be the case if an individual was prosecuted. ${ }^{10}$

The fishery sector is one of the sectors that has the greatest potential in optimizing the state revenues, on the other hand it can also be a source of reduction to the state revenues if companies or corporations commit the illegal action, Illegal practices, Unreported, Unregulated (IUU) Fishing practices that intended only to increase the assets of the corporation's own wealth. ${ }^{11}$ For that reason, the Fishery Law regulated corporate criminal liability in order to eradicate IUU Fishing conducted by the corporations. According to Article 1 Paragraph 14 of the Fishery Law, the legal persons are natural person or corporations meaning they can conduct any illegal fishing act thus should be imposed criminal liability.

Even so, based on Article 101 of the fishery law, the corporation shall not be held criminally liable by the reason the claims and penalties will be imposed on its managers instead. As one of the economic crimes, IUU Fishing is mainly committed to gain profit, driven by growing world demand for fish and other seafood, and the globalization of the market. ${ }^{12}$ Consequently, the crime must be committed in the exercise of business activities, meaning that the crime cannot be committed by individuals other than employees or others working on behalf of a corporation. ${ }^{13}$

\footnotetext{
${ }^{9}$ Vijay Veer Singh, Corporate Criminal Liability: A Critical Legal Study, International Journal of Research And Analytical Reviews, Volume 5I Issue 2I April - June 2018

${ }^{10}$ Catherine Elliott and Frances Quinn, Criminal Law, 8th edition, (England: Pearson Education Limited, 2010) at 308 retrieved from Ayu Izza Elvany, Formulation Policy Regarding the Smuggling of Lobster Seeds in Indonesia, Lentera Hukum, Volume 7 Issue 1 (2020), pp. 37-54

${ }^{11}$ Rahadi Wasi Bintoro et. al.,, supra note 7

12 The Pew Charitable Trusts, FAQ: Illegal, Unreported, and Unregulated Fishing, 2013.

${ }^{13}$ Prop. 1985/86:23, om ändring i brottsbalken m.m. (företagsbot) 28-29 retrieved from Elvira Näs \&Michael Nyman, Corporate Criminal Liability In Sweden-Corporate Fines From A Critical Perspective, Compliance Elliance Journal, Volume 5 Number 2, 2019
} 
Therefore, the corporation shall be held criminally liable for committing IUU Fishing. Fortunately, the draft of fishery law not only recognizes corporation as a legal person but also can be held criminally liable, as the Article 1 Paragraph 26 and Article 153 Paragraph (1) stated that every person is any natural person or corporation, either in the form of a legal entity or not, thus in case that the criminal offences are committed in the name of, or on behalf of a corporation, the penalty will be imposed on the corporation and/or its managers. However, the enactment of Job Creation Law changed corporate criminal liability regulation in fishery law.

Corporate criminal liability regarding IUU Fishing which rules in the Job Creation Law is quite similar to the draft of the fishery law as compared below:

\begin{tabular}{|c|c|}
\hline The draft of Fishery Law & \multicolumn{1}{|c|}{ The Job Creation Law } \\
\hline $\begin{array}{l}\text { Article 153 Paragraph (1): "...in case } \\
\text { that the criminal offences are committed in } \\
\text { the name of, or on behalf of a corporation, the } \\
\begin{array}{l}\text { penalty will be imposed on the corporation } \\
\text { and/or its person in charge." }\end{array}\end{array}$ & $\begin{array}{l}\text { Article } 27 \text { Paragraph (34): "..in case } \\
\text { that the criminal acts are committed by } \\
\text { corporations, the charges and the penalties } \\
\text { will be imposed on both the employee and } \\
\text { the corporation." }\end{array}$ \\
\hline
\end{tabular}

The table above shows that the Job Creation Law both recognizes corporation as a legal entity and can be imposed criminal liability. Yet, there two points that differ it from the Draft of the Fishery Law. Firstly, the conjunctions used in the latter are 'and/or' meaning that the criminal liability can be imposed both on the corporation and its employee or only one of them, either the corporation or the employee. In the meanwhile, the former uses 'and' meaning when IUU Fishing is committed by a corporation, both the corporation and its employee shall be held criminally liable.

Imposing corporate criminal liability can be done with the provision that law enforcement officials have to prove the existence of reasonable attribution, which is the relation between the conduct of an individual and the corporation, whether the conduct is done on behalf of the corporation, or it is within the scope of corporation's activities, or the corporation gained benefit from it. ${ }^{14}$ Thus the corporation can be held liable and be sentenced for the criminal offence. ${ }^{15}$ At the same time, regarding the using of 'and' in the Job Creation Law, law enforcement officials have to prove not only the reasonable attribution but also mens rea of its employee whereas the using of 'and/or' in the draft of Fishery Law make it more flexible for enforcing it since the corporation can be held criminally liable despite the mens rea of its employee have not proven yet. ${ }^{16}$ Hence the Job Creation Law needs to be amended, specifically its article concerning corporate criminal liability, by changing the used conjunction to 'and/or, as regulated in the draft of Fishery Law as well.

Lastly, the terms to define 'employee' used in both laws are different. The former uses the term 'person in charge' whereas the latter uses the term 'employee'.

\footnotetext{
${ }^{14}$ Indonesia Ocean Justice Initiative, Analisis UU Cipta Kerja Sektor Kelautan dan Perikanan, https://oceanjusticeinitiative.org/wp-content/uploads/2020/10/IOJI-Analisis-UU-Cipta-Kerja-Sektor-Kelautan-danPerikanan

${ }^{15}$ Ibid

${ }^{16} \mathrm{Ibid}$

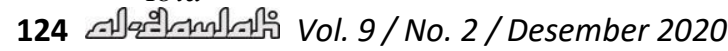


Indonesia Ocean Justice Initiative argued that the letter term is more limited since it is only interpreted as the ones being listed in the corporate management ladder, than the former. ${ }^{17}$ The term 'person in charge' is understood as not only the employee listed in the ladder but also the beneficial owners. ${ }^{18}$ Relating to this matter, Article 47 of the Draft of Indonesian Criminal Code (RUU KUHP) stipulated that a criminal offence can be committed by a person who is not listed in the corporation's management structure yet has control over, or is the beneficial owner of the corporation, and can give the order of the offence. ${ }^{19}$ Accordingly, as the term of 'person in charge' is more appropriate, in case of corporate criminal liability system, than the one used in the Job Creation Law, which is 'employee', the Job Creation Law shall be revised by opting the former term into it.

\section{CONCLUSION}

Following the enactment of the Job Creation Law on $5^{\text {th }}$ October 2020, some articles of Law No. 45 of 2009 amending law no. 31 of 2004 concerning Fishery are amended, including the corporate criminal liability regulation. As a penal policy of Illegal, Unreported and Unregulated (IUU) Fishing eradication, the Fishery Law regulates criminal law as one of its enforcement instrument. This research analyses further how is corporate criminal liability regulation in Indonesia regarding IUU Fishing following the enactment of the Job Creation Law since IUU Fishing, as stated above, is not only committed by natural person but also a corporation.

Article 101 of the fishery law stipulated that the corporation shall not be held criminally liable by the reason the claims and penalties will be imposed on its managers instead. Meanwhile, Article 1 Paragraph 26 and Article 153 Paragraph (1) of the draft of Fishery Law stated that every person is any natural person or corporation, either in the form of a legal entity or not, thus in case that the criminal offences are committed in the name of, or on behalf of a corporation, the penalty will be imposed on the corporation and/or its managers. However, the enactment of Job Creation Law changed corporate criminal liability regulation regarding IUU Fishing.

Although both the Job Creation Law and the draft of fishery law recognize a corporation as a legal entity and can be imposed criminal liability, there some points that differ those laws, which are the used conjunction and the terms to define 'employee'. Based on this research's analyses, in order to improve the effectiveness of IUU Fishing law enforcement, specifically the ones being committed by a corporation, the Job Creation Law needs to be amended, specifically its article concerning corporate criminal liability, by changing the used conjunction to 'and/or, as regulated in the draft of Fishery Law as well. Furthermore, as the term of "person in charge' is more appropriate, in case of corporate criminal liability system, than the

\footnotetext{
${ }^{17}$ Ibid

${ }^{18}$ Ibid

${ }^{19}$ Ridzki Putra Ramadhan, Draft of New Indonesian Criminal Code and the Potential Impact on Corporations, SSEK Indonesian Legal Consultants, online: https://www.ssek.com/blog/draft-of-new-indonesiancriminal-code-and-the-potential-impact-on-corporations
} 
one used in the Job Creation Law, which is 'employee', the Job Creation Law shall be revised by opting the former term into it.

\section{References}

Ayu Izza Elvany, Formulation Policy Regarding the Smuggling of Lobster Seeds in Indonesia, Lentera Hukum, Volume 7 Issue 1 (2020)

Elvira Näs \&Michael Nyman, Corporate Criminal Liability In Sweden -Corporate Fines From A Critical Perspective, Compliance Elliance Journal, Volume 5 Number 2 (2019)

Henry Dianto Pardamean Sinaga et. al., Reconstruction of Corporate Criminal Liability in Indonesia, International Journal of Advanced Science and Technology Vol. 29, No. 08, (2020)

Indonesia Ocean Justice Initiative, Analisis UU Cipta Kerja Sektor Kelautan dan Perikanan, https://oceanjusticeinitiative.org/wp-content/uploads/2020/10/IOJIAnalisis-UU-Cipta-Kerja-Sektor-Kelautan-dan-Perikanan

Maradona, Corporate Criminal Liability in Indonesia: Regulation, Implementation and Comparison with The Netherlands, Thesis, Erasmus school of law, (2018)

Muladi dan Dwidja Priyatno, Pertanggungjawaban Korporasi, Jakarta: Kencana Prenada Media Group, (2012)

Oksimana Darmawan, Pertanggungjawaban Pidana Korporasi Dalam Illegal Fishing Di Indonesia, Jurnal Yudisial Vol. 11 No. 2 (2018)

Rahadi Wasi Bintoro et. al., Corporate Criminal Liability towards The Doer of Illegal, Unregulated and Unreported Fishing in Indonesia, E3S Web of Conferences 47, 06003 (2018)

Ridzki Putra Ramadhan, Draft of New Indonesian Criminal Code and the Potential Impact on Corporations, SSEK Indonesian Legal Consultants, https://www.ssek.com/blog/draft-of-new-indonesian-criminal-code-and-thepotential-impact-on-corporations

The Pew Charitable Trusts, FAQ: Illegal, Unreported, and Unregulated Fishing, (2013)

Vijay Veer Singh, Corporate Criminal Liability: A Critical Legal Study, International Journal of Research And Analytical Reviews, Volume 5I Issue 2I (2018)

Vikrant Sopan Yadav, Corporate Criminal Liability: A Comparative Analysis of Judicial Trend, International Journal of Applied Research 1(10), (2015)

Yudi Krismen, Pertanggungjawaban Pidana Korporasi Dalam Kejahatan Ekonomi, Jurnal Ilmu Hukum Volume 4 No. 1 (2014) 